\title{
GENDER DisCRimination IN PURCHASE AND SALE IN CROATIAN CONSTRUCTION
}

\author{
Andrea Denk \& Helena Nikolić
}
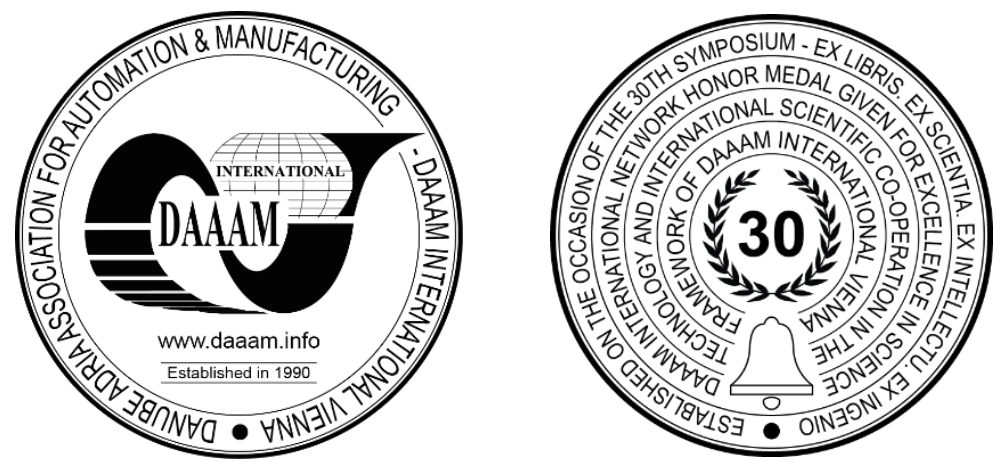

This Publication has to be referred as: Denk, A[ndrea] \& Nikolic, H[elena] (2020). Gender Discrimination in Purchase and Sale in Croatian Construction, Proceedings of the 31st DAAAM International Symposium, pp.0661-0667, B. Katalinic (Ed.), Published by DAAAM International, ISBN 978-3-902734-29-7, ISSN 1726-9679, Vienna, Austria DOI: $10.2507 / 31$ st.daaam.proceedings.092

\begin{abstract}
The construction sector carries a number of distinctive features compared to other economic activities; from the size of the sector itself, the high initial costs, the nature of demand, to the length of the manufacturing process and the role of the state. In addition, construction is a specific sector dominated mainly by the male population. Nevertheless, more than $10 \%$ of the female population in Croatia are employed in construction. Assuming that women in that industry are undervalued, the paper sought to examine the presence of gender discrimination in the procurement and sales segment and to identify the factors that cause unfairness. Given the wide range of literature on this topic, the paper summarizes the most important manifestations of discrimination against women in the labour market. Methods for combating this problem are presented, linking the entire segment with the construction industry, as well as procurement and sales processes in which gender discrimination is supposedly evident. The topic was further explored through in-depth interviews with female construction employees.
\end{abstract}

Keywords: Discrimination; Women; Construction sector; Croatia; Purchase; Sale

\section{Introduction}

Personal dignity and basic human rights are violated by putting any person at a disadvantage based on their own descriptive trait. The modern economy has placed great emphasis on equality. So, considerable efforts are being made to eradicate and penalize discriminatory acts. Discrimination is particularly visible in a labour market where competition prevails. Most legal systems strictly prohibit discrimination. However, women are still very often exposed to homophobia because of prejudices and distorted beliefs that are instilled through culture. Discrimination is most often reflected in financial inequality and reluctant employment of women, ethnic groups and/or minorities. In addition, discrimination in education and promotion is noticeable. It is expressed in unfair evaluation of certain jobs and intentional limiting the availability of certain occupations. Discrimination is also manifested through systematic belittling, victimization and sexual harassment [1], [2].

For example, in Croatia the average wage gap is between 10 and 20\% [3], and fixed-term employment is contracted by a significantly larger number of women than men [4]. This indicates the fact how much the distrust and suspicion of employers in women's business abilities is expressed, as well as the need for greater proof. 
The possibilities of pregnancy and parenthood also have a negative connotation, which further degrades women in the business world [5]. In 2007, a survey found that $48 \%$ of women encountered job advertisements where gender was a prerequisite, and $36 \%$ did not notice in the advertisements that people of both sexes could apply for a job. Furthermore, in more than $60 \%$ of cases, marital status and family issues were interfered with in job interviews [6]. The Faculty of Philosophy came to the same cognition in their research. Among the results, the fact that $9 \%$ of respondents experienced some form of sexual discrimination during job interviews stands out and the connection between pregnancy and dismissal is obvious [7]. The problem of discrimination is additionally reflected in the accompanying actions, ie reactions to the experienced injustice. Namely, Portal Moj Posao conducted a survey and found out that most respondents would not take any action if they felt discrimination in the selection process. They are aware that discrimination is possible, they are consciously looking for a job under these conditions and in the case of a discriminatory outcome they wouldn't react [8].

From the above, it can be seen that discrimination is ubiquitous and expressed in the initial steps in the labour market. As business relations are more complex and the money segment comes to the fore, it is expected that injustice and irregularities are becoming even more pronounced. It is also likely that homophobic behaviours are more common in those industries where women are a rarity, such as the construction sector. Therefore, the main objectives of this paper are: (i) to point out the problem of gender discrimination; (ii) to identify emerging forms of discrimination against women in the labour market (iii) to summarize the methods of combating it, (iv) to investigate the presence of gender discrimination in relatively male economic activity and (v) to draw conclusions based on research results.

The paper is organized as follow: after the introduction, a brief overview of the construction sector in Croatia is given. In the third part, the emphasis is on the issue of gender discrimination. Types of discrimination against women in the labour market are described and methods of combating discrimination against women are consolidated. The fourth part presents the research methodology. This is followed by results and discussion. At the end of the paper is the conclusion.

\section{Construction sector in the Republic of Croatia}

The construction sector is a specific secondary activity. In addition to a wide range of complex operations and significant financial capital, it is characterized by the ubiquitous role of the state [9], [10]. Namely, the state provides public infrastructure and appears in the role of an investor with the aim of initiating development and creating employment [11]. The construction sector encourages the development of other ancillary activities such as mining and quarrying, manufacturing and business services [12]. It can be concluded that construction is of a great importance for the national economy in every respect, which can be seen from the main sectoral indicators (Table 1). In addition to the effect on aggregate production of about $4 \%$, its contribution to total employment (7\%) is also unavoidable. According to the latest data from the Central Bureau of Statistics (June 2019), the number of employees in this sector was 101.374. Of the total number of employees in construction, women make up about $11.5 \%$, which indicates one of the most pronounced differences between the number of employees in Croatia [13].

Until 2008, construction was one of the most expansive activities in the Republic of Croatia. But the nature of demand for construction products is very unpredictable and prone to frequent fluctuations which puts an additional challenge on this industry [14]. Namely, the economic crisis hit this sector the hardest and stopped the long-term trend of strong growth. The construction industry in Croatia has had a much harder time withstanding the recession than other members of the European Union. However, after six years of crisis, the negative trends are slowing down and the first signs of recovery are visible. There is an intensive growth of issued permits, volume of construction works and employment, as well as the number of newly built apartments. The recovery is a consequence of continued growth in activities in other sectors (tourism, transport and industry).

\begin{tabular}{|c|c|c|c|}
\hline & $\mathbf{2 0 1 3}$ & $\mathbf{2 0 1 5}$ & $\mathbf{2 0 1 8}$ \\
\hline Share in GDP & 4,5 & 4,2 & 4,4 \\
\hline Share in total employment & 7 & 6,5 & 7,0 \\
\hline Volume of construction works (\% changes) & $-4,7$ & $-0,7$ & 5,0 \\
\hline Number of employees (\% of changes) & $-6,4$ & $-1,3$ & 4,3 \\
\hline Completed dwellings (\% of changes) & $-14,4$ & 3,3 & 19,4 \\
\hline Building permits issued & $-19,7$ & -4 & $-0,1$ \\
\hline Price of sold apartments (\% of changes) & $-9,9$ & 1,6 & 6,8 \\
\hline
\end{tabular}

Table 1. Main sectoral indicators

The total value of construction works in 2018 amounted to HRK 19.2 billion, which is still very far from the results from the pre-recession period (HRK 34.9 billion). The largest share is occupied by non-residential buildings and transport infrastructure. However, there are no major infrastructure projects, so there is no stronger momentum in the construction sector. Wages in construction also lag behind the average. In the first 7 months of 2019, the average net salary in construction was $18.3 \%$ lower than the average net salary in Croatia. Interestingly, at the state level, men earn on average more than women. However, this is not the case in construction [15]. Nevertheless, this difference in income can be attributed to the fact that the vast majority of employed men perform heavy physical work on the construction site, and it is known that the nature of such work entails small salaries. 


\section{The issue of gender discrimination}

\subsection{Types of discrimination against women in the labour market}

The position of women in society has changed greatly. From a purely maternal role and home environment, they have become an integral part of the global economy [16]. Women's work has significantly contributed to the development of certain economic activities. Thanks to the development of society, technology and emancipation, they have acquired numerous rights and a renowned status in the labour market. Despite the equality achieved, they are still discriminated against in the workplace often, through pay and poorer opportunities for promotion. They face gender segregation (traditional division into male and female occupations), horizontal segregation (focusing exclusively on services, education, textile industry and administration while qualified and physically demanding jobs are inaccessible to them) and vertical segregation (women are employed in lower paid jobs) [17].

Zwiech 2009 distinguishes five forms of discrimination against women in the labour market: employment discrimination, professional discrimination, position discrimination, discrimination in the access to training and pay discrimination. Discrimination in employment prevents women from finding a job because of the characteristics that the employer is looking for. They tend towards specifics that are possessed exclusively by men. It results in a higher unemployment rate of the female population. Professional discrimination occurs when there are arbitrary restrictions on access to certain occupations and different employment conditions for the same position between men and women. Position discrimination is actually associated with vertical segregation as it most often takes into consideration leading positions in the company that are predetermined on the basis of gender. Discrimination in access to training encroaches on the sphere of human capital. Namely, it prevents women from education, access to databases, professional development and gaining additional experience. Finally, there is pay discrimination, which is reflected in a large income discrepancy between women and men with the same qualifications, in the same positions and for the same workload. Judgment is not objective and employee efficiency is put in the background [18].

In addition, discriminatory actions in women's professional careers are reflected in: decision-making inequality, sexual discrimination and the phenomenon of the glass ceiling. Decision inequality occurs in all economic sectors and implies rigid uniform gender roles in which women's attitudes and opinions are not important or are less important [19]. Sexual discrimination comes to the fore in employment where it encroaches on women's private lives and their plans for the future [20], [21]. The phenomenon of the glass ceiling is a state of insufficient representation of women in leading positions on the labour market. The glass ceiling is a symbol of an invisible obstacle that is noticed only when an individual personally experiences it. This discrimination is manifested by blocking a woman's career at some point. Namely, despite her knowledge and abilities, she is not allowed to make a progress. She stagnates and becomes untapped potential thus losing confidence and courage in business [22].

\subsection{Methods of combating discrimination against women}

Unfortunately, there are no universal methods to combat discrimination. Most authors deal with the issue of discrimination, its division and presence in all its forms, but few have really commented on solving this problem with concrete scientific methods. The literature states that Western countries have developed a range of anti-discrimination policy measures. These include improving the education and training of discriminated groups of workers and monetary and fiscal policy measures [23]. More specifically, it is about insisting on equal pay, child allowance for all children and job security after maternity leave. Stricter penalties for unequal treatment, respect for equality during education, public awareness and education about gender equality are also mentioned [24].

Many European countries insist and encourage the employment of women precisely to show that they are leading the fight against discrimination. However, indirect discrimination is still strongly present! The treatment of women and men remains unequal, despite the legislation, because discrimination always comes at a higher cost than effort. Namely, the key is to change attitudes because the fight for equality is actually a benefit only for women. On the other hand, men should be against something that means the loss of their privileges. Therefore, two basic principles stand out as a solution. The principle of "class action" according to which the discriminated are protected as a specific, peculiar, group and the principle of "respect for contracts" according to which the provision of equal opportunities is encouraged. Additionally, there is a method aimed at encouraging or punishing those who ignore the problem of discrimination by tax policy [25].

The modern economy has made a shift from empowering equality to proactive politics. Thus, the techniques of analysis on the objective conditionality of discrimination and the possibilities of influencing it are applied, as well as the technique of making plans for equality in those cases where it has been determined that there are no equal opportunities for men and women. Gender main streaming is of fundamental importance and represents a basic pillar that should be respected at all levels of decision making [26].

Methods, which are listed below, are a synthesis of the proposals of various authors who have tried to devise methods for gender equality in the labour market. Equal opportunities policy is the recommended method in the "Guide to Promoting Equal Opportunities in the Workplace". The key is to appoint a team or individual, depending on the size of the company, that will receive employee complaints regarding gender discrimination. The Gender Discrimination Coordinator would then review the complaints, examine their justification, and consult with executives. 
Finally, they would work together to design and organize a work policy that would eliminate discrimination against women in the company, with an emphasis on the possibility of advancement and education [27]. The disadvantages of this method consist in the subjective attitude and questionable competence of the coordinator and the impossibility of quantifying the data that could be used to assess the success of the method. Seminars on gender equality in the labour market should become a practice in all companies. They would have an advisory and support function on the legal and professional side that is covered by the media. Despite computer literacy, ignorance of rights is clearly present, and discrimination is a taboo topic in modern society. Therefore, through the method of "Silence is not gold", the active expression of this issue would be promoted [28].

The Law on Gender Equality introduces special measures that represent specific benefits of equal participation in public life, eliminate existing inequalities and ensure previously denied rights. It is important to emphasize that such measures are temporary and there is no legal obligation to apply them. Therefore, the Law seeks to activate state bodies, legal entities with public authority and local self-government units to implement special measures and adopt plans to promote and establish gender equality. Examples of such measures are: publicity of job vacancies, clear emphasis on objective and reasonable requirements, strictly defined additional qualifications in the next elimination round, in the case of a transfer to a higher-paid position and two or more candidates have the same qualifications, priority will be given to the candidate of the same sex as the under-represented [29].

The method of collective action through associations, unions and societies achieves the best results. Hence, it is necessary to introduce conditions that would enable women to participate and be representatives of such organizations. The emphasis would be on creating a secure link between family and career because in this field women are discriminated against the most and unprotected [30]. The union should provide more flexible working hours or at least advocate for better conditions for young mothers when returning to work after maternity leave [31].

\section{Methodology}

The paper presents a qualitative survey of the female population employed in the construction sector. The perceptions of profession and experience in operating and selling products and services to clients were examined. The qualitatively expressed determinants of gender discrimination in construction were initially analysed. They were grouped into four content preferences: (i) years of work experience in construction in general and the importance and nature of their own business, (ii) positive and negative perceptions of the profession, (iii) discrimination in general and (iv) discrimination in the sale of products/services. In-depth interviews were conducted among women in various positions in the company (CFOs, Chief Designers, Site Managers). This was precisely the main starting point in the research as it provided insight into the current nature of the work. The prerequisite was that they had relatively similar work experience. In other words, that they were involved in construction as well as in interactive activities with subcontractors, designers and business colleagues. Also, in order to gain a better insight into the nature of the job, respondents needed to have more than 10 years of service. In-depth interviews were conducted in smaller communities in the Republic of Croatia - the area of OsijekBaranja County, namely in the two cities Valpovo and Belišće. These two towns have a long tradition in construction business. Five women from the construction industry participated in the research. Exploration was conducted during August 2017. Respondents were asked 33 questions in total. An average duration of the interview was sixty minutes.

\section{Results}

Exploration of women in the construction sector through a qualitative methodology has yielded interesting results. Regarding the positive and negative attitudes about the perception of women in construction, the observations are equivalent. What is stated as a negative aspect of the construction sector towards women is the expressed need to prove expertise and insufficient feedback and recognition for successfully completed work. They also point out that they have encountered the problem of difficult contracting. On the other hand, as positive elements of the vocation they state the intensive interaction with people that results in the acquisition and expansion of acquaintances.

The third substantive determinant of the in-depth interview refers to discrimination in general in cooperation with colleagues in the office and on the construction site. All respondents had a male supervisor and two respondents collaborated exclusively with male colleagues. In the team, everyone had the same educational status, work position and work experience. Nevertheless, one respondent had a negative experience in the office from a superior who preferred a male colleague regardless of the same workload. She was exposed to negative comments. The superior clearly pointed out the doubt in the work tasks and professional attitudes of the female employee. Discrimination manifested itself through the categorical ignoring of a female colleague in all fields of cooperation. In addition, discrimination and belittling were reflected through the superior's knowledge of the respondent's private situation and was used as a manipulative tool in her work. Furthermore, during the work on the construction site, they felt that they represented an "attraction" and that they were observed with special interest. Still, none of them had unpleasant experiences with construction workers. They experienced exclamations and similar mockeries. However, they attributed this to the indispensable nature of such communication in the field. Two out of five respondents experienced a lack of authority on the construction site between colleagues due to gender identity. Meanwhile, they partly attributed that to a lack of work experience. The fourth part of the research emphasizes discrimination in the sale of products and services. In the last part of the in-depth interview, the respondents were exposed to specific questions related to the conclusion of jobs and the way they provide services in 
construction. When asked about the activities of suppliers, three out of five respondents answered that bids are constantly late. The remaining two respondents believe that the delay in bids is not due to the gender identity of women, but to incompetence in business. Furthermore, when asked about the consideration of job offers, two out of five respondents have the authority to place offers, but the final word is given by the superior, the head of the company. None of them considers this part as discriminatory item. Regarding the inclusion of women in the process of selling real estate, it was unanimously concluded that this is not a practice. One respondent note that the sale is more or less "public secret". However, the price is strictly hidden by superiors. However, no respondent considers this part to be sex discrimination. When it comes to the meetings, respondents are divided. Three respondents met regularly with clients and potential business associates, while two did not perform such an approach. Nevertheless, they do not attribute this to gender discrimination. Respondents who went to business meetings did not feel that their opinion was not taken into account or that they were deprived of business because of their gender identity. However, all respondents agreed that it is much easier for men to establish business cooperation. Namely, contracting usually takes place in an informal environment (at lunches, dinners and through men's gatherings). It is delicate for women to expose themselves to such situations. Therefore, concluding deals is visibly difficult.

When asked whether the superior used the gender identity of the respondents for the purpose of solving business problems or contracting jobs, four respondents answered affirmatively, but in a positive sense. In other words, respondents did not feel that they were victims of discrimination. However, one respondent pointed out that she was exposed to a delicate situation. Namely, the superior required her to be a mediator in solving the problem with the subcontractor since she is a woman.

When asked if the respondents were deprived of any business cooperation due to their gender identity, they unanimously agreed that they were not. Nevertheless, there have been impostures attributed to gender discrimination. The respondent was exposed to underestimation by a business partner who categorically refused any kind of normal cooperation with a female worker. Unable to avoid collaboration and believing in a lack of women's business skills, he tried to modify the project in his favour. However, due to the expertise and thoroughness of the respondent, he failed in his intention. Still, the respondent does not deny that she felt gender discrimination as well as a sense of inferiority.

In the end, all respondents emphasized that they have enough responsibilities and authority and are satisfied with the working environment. Likewise, all respondents are satisfied with the job they are currently doing. They also generally conclude that discrimination does not exist.

\section{Discussion}

After conducting in-depth interviews, we come to the conclusion that the respondents alleviate the discriminatory moments they experienced in business. Although the respondents emphasized that they had difficulties in the business environment, they subjectively refer mainly to the present circumstances when they became renowned experts in their work. Leaving past experiences behind, they mostly deny discrimination and do not consider disputable situations as unrighteousness. However, they have undoubtedly experienced discrimination in several fields. Discrimination was clearly manifested in the inability to conclude deals, their excessive work and the feeling that they had to prove themselves much more. Furthermore, supervisors and colleagues ignored their business results and they experienced unprofessional communication on the construction site. All controversial actions indicate aversion and doubt in the expertise of women in construction. Also, the absence of feedback and praise indicates discrimination. Colleagues and superiors do not have the need to express satisfaction with the results since they were achieved by a female person.

Due to the predominantly male environment, they feel less valuable and self-doubtful. Therefore, they are thorough and distrustful, they question their own decisions and are afraid of failure which again indicates the invisible discrimination they felt. It is evident that for each negative experience, the respondents have a "justification" and an explanation, mostly finding the culprit in themselves or the circumstances. Precisely speaking, dishonesty and degradation are attributed to a lack of work experience, and informal communication is justified as a part of everyday life on the construction site. However, the question arises, why such communication is not present when a man appears on the construction site if it is a normal type of conversation? Why, after years of work experience and acquaintances, has such communication become decent and minimized? In our opinion, many years of work experience, hard work and proven expertise have actually resulted in respect, appreciation, current job satisfaction and in creating a sense of belonging in the environment in which they work.

Furthermore, all respondents stated that as women they served to solve problems or conclude contracts. In other words, it was thought that they could represent a greater attraction in the eyes of potential business partners. They have not identified it as gender discrimination, but it is evident that it is precisely a form of exploitation of gender identity. Fortunately, such challenging situations ended positively and without incident however the question is what would have happened if the outcome had been problematic. Going deeper into the issues of the researched topic and the obtained results, we believe that the denial of discrimination can be attributed to the environment. The familiar environment solves in some way the mystery of the presence of gender discrimination in the segments of procurement and sales. The two small towns in which the research was conducted are highly developed in terms of construction.

Several small private construction companies operate in them and they all cooperate. Through numerous completed projects, acquaintances, partnerships and friendships have been created. Therefore, it is very difficult to speak openly about discrimination. Notwithstanding all the above, emphasis should also be placed on the fact that in cases of 
discrimination, no concrete action has been taken to eradicate it. Why is that so? It is not clear. Is there a fear of losing a job or some other factors represent an issue? It is a common belief that there is no point in occupying problematic situations and creating a potentially even bigger problem as nothing will be achieved. Howsoever, this is definitely a big problem of the whole society. The best way to combat the discrimination is definitely the education and awareness about personal capabilities, which should not have a cause-and-effect relationship with sexual characteristics. Finally, the fact that one in five respondents made it clear that she had been exposed to negative comments by her superior should not be overlooked. Therefore, it can be concluded that at least every fifth woman experienced the same. We also believe that this number increases linearly with the growth of employees in the company which is somewhat confirmed through the experience of the respondent whom they underestimated and tried to deceive. In an unknown and larger environment, subjects of different cultural characteristics meet. This entails greater exposure to tolerance but also to narrow-minded thinking which results in discrimination very often.

\section{Conclusion}

Modern society is characterized as a period in which humanity is proud of freedom, democracy, modern way of living and thinking. It is a time when people are allowed to be who they really are without prejudice and questions. However, theory often differs from practice. Discrimination is a reality of every country and is especially pronounced in less developed economies. In Croatia, there is still insufficient information of both, employers and workers, on basic rights and obligations. Rules of conduct, communication and actions are often conditioned by prejudice and cultural attributes. Therefore, mild forms of homophobic outbursts go through unnoticed very often. Indeed, they are perceived as normal.

Discrimination against women in the labour market occurs in many forms and at all stages of business. The most common forms of discrimination are: limited employment opportunities, reduced opportunities for education and promotion, differences in salaries, predestination for specific occupations and positions and inability to make decisions. The legislative framework has been established in most countries. However, latent discrimination is pervasive. Discrimination, as an eternal taboo and a ubiquitous segment of every sector, should be taken seriously and fought with perseverance. Given the many manifestations of discrimination, there is no universal method of combating it. Gender main streaming and proactive policy are the priority. Emphasis is on dealing with situations where discrimination seems inevitable. Some of the proposed solutions include: the interaction between discriminated groups, defining working groups in charge of discrimination within the company, implementation of special, exceptional, legal provisions, penalties for unequal treatment and intense education about rights and responsibilities. Basically, all methods involve a change of consciousness. In other words, the ultimate goal is to implement the method of active action and response to discriminatory actions. That is, that silence is the exception, not the rule.

The research was conducted in the procurement and sales sector as this process is general and universal for all sectors. The construction sector was chosen because it is of a great importance to the national economy. Likewise, it is very challenging, sensitive and vulnerable to economic developments and what is the most important fact - women are not the usual workforce. That is why it was very interesting to link discrimination to construction; explore women's attitudes, study their contribution, involvement and sense for discrimination. The research was conducted by a qualitative method of in-depth interview among five respondents. It was concluded that the environment is the most important and main segment of the existence of discrimination but also of her denial and non-response to it. Women are sceptical and consequently very thorough in their work. There were certainly inappropriate comments, lack of authority, delicate situations and dishonest actions. Scepticism and homophobia came to the fore especially after the change of the known work environment, associates and subcontractors. The ability of a woman to do a job as successfully as a man's was also questioned. But respondents globally downplay the effects of discrimination and did not react to segregation and mobbing what is worrisome.

The research is very personalized so it carries certain restrictions. The first limitation of this research may be the limitation of the data collection method. Namely, the aversion of the respondent towards the examiner is questioned since anonymity does not exist. Also, it is possible for the respondents to be ashamed of admitting certain experiences. Moreover, calculating in providing answers is also possible since this is a very delicate topic. One of the main limitations of the research is the number of respondents. Although in-depth interviews can lead to very thorough answers, it is certain that if the number of respondents had been higher, more expanded answers would have been reached.

Another limitation is certainly the territorial area in which the research was conducted. Emphasis is placed on only one industrial sector which is also a limiting factor. Therefore, the main recommendations for the future research on this topic could include the following: utilization of another research method, engaging more respondents, consideration of another industry and diversification of respondents according to selected criteria. One of the main recommendations for future research would certainly include the fundamental question: "What would you do if you felt discriminated against?"

\section{References}

[1] McConnell-Ginet, S. (2010). Gender, sexuality, and meaning: Linguistic practice and politics. Oxford University Press.

[2] Rhode, D. L. (1991). Justice and gender: Sex discrimination and the law. Harvard University Press. 
[3] Vučemilović, V. (2015). Distribution Channels of Major Construction Materials. Business Logistics in Modern Management, pp. 131-141. Available at: http://hrcak.srce.hr/ojs/index.php/plusm/article/view/3877 Accessed: 2020-05-05

[4] Kulušić, J. (2009). Isplati li se fleksibilnost: hrvatsko tržište rada (Does flexibility pay off: the Croatian labor market). TIM Press.

[5] Ljubičić, V., \& Petrović, J. (2012). Kako prepoznati spolnu diskriminaciju u praksi i kako se od nje zaštititi (How to recognize sex discrimination in practice and how to protect yourself from it). Zagreb, Bestias dizajn doo.

[6] Galić, B., \& Nikodem, K. (2009). Neki aspekti diskriminacije žena pri zapošljavanju u Republici Hrvatskoj. Rad u Hrvatskoj: pred izazovima budućnosti (Some aspects of discrimination against women in employment in the Republic of Croatia. Work in Croatia: facing the challenges of the future). Zagreb: Centar za demokraciju i pravo Mirko Tripalo, Pravni fakultet sveučilišta u Zagrebu.

[7] Kamenov, Ž; Galić, B (2011). „Rodna ravnopravnost i diskriminacija u Hrvatskoj“ (Gender equality and discrimination in Croatia). Ured za ravnopravnost spolova Available at: http://www.uredravnopravnost.hr/site/images/pdf/dokumenti/rodna\%20ravnopravnost\%202.pdf Accessed: 202005-18

[8] https://www.moj-posao.net/Press-centar/Details/69440/Razlike-u-placama-zena-i-muskaraca-i-dalje-se-nesmanjuju/2/ (2009), Accessed on: 2020-05-01

[9] Ofori, G. (1990). The construction industry: aspects of its economics and management. NUS Press.

[10] Medanić, B. (2005). Recentna razina i bonitet upravljanja i rukovođenja u hrvatskom građevinarstvu (Recent level and creditworthiness of management and leadership in Croatian construction). Ekonomski pregled, Vol. 56, No. 9, pp. 684-705.

[11] Polenske, K. R., \& Sivitanides, P. (1990). Linkages in the construction sector. The Annals of Regional Science, Vol. 24, No. 2, pp. 147-161.

[12] Buturac, G. (2017). Sektorske analize: Građevinarstvo i nekretnine (Sector analyzes: Construction and real estate). Sektorske analize, Vol. 6, No. 56, pp. 1-24.

[13] https://www.eizg.hr/userdocsimages/publikacije/serijske-publikacije/sektorske-analize/SA_Gradevinarstvo2019.pdf (2019). Ekonomski Institut Zagreb, Sektorske analize, Accessed on: 2020-05-17

[14] Weddikkara, C., \& Devapriya, K. (2001). Demand and supply trends and construction industry development: a case study in the Sri Lankan construction industry. Construction Economics and Building, Vol. 1, No. 1, pp. 91-105.

[15] https://www.dzs.hr/Hrv_Eng/ljetopis/2018/sljh2018.pdf (2018). Croatian Bureau of Statistics, Statistical Yearbook of the Republic of Croatia, Accessed on: 2020-05-17

[16] Adkins, L. (1995). Gendered Work. Sexuality, Family and the Labour Market. Open University Press, 1900 Frost Road, Suite 101, Bristol, PA 19007, ISBN: 0-335-19297-1, ISBN: 0-335-19296-3.

[17] Charles, M., \& Grusky, D. B. (2005). Occupational ghettos: The worldwide segregation of women and men, Stanford, CA: Stanford University Press.

[18] Zwiech, P. (2009). Discrimination against women in professional life in chosen pro-feminist theories. Economics \& Sociology, Vol. 2, No. 1, pp. 96.

[19] Balon, B. (2007). Rodno senzitivna statistika kao neophodan element u demokratizaciji društva (Gender sensitive statistics as a necessary element in the democratization of society). Stanovništvo, Vol. 45, No. 1, pp. 79-95.

[20] Chiplin, B., \& Sloane, P. J. (1976). Sex discrimination in the labour market. Springer.

[21] Kokanović, M. et al. (2000). Diskriminacija žena u Hrvatskoj (Discrimination against women in Croatia). Ženska sekcija SSSH, Zagreb.

[22] Jergovski, A (2010.). Stakleni strop. Granice u napredovanju žena na radnom mjestu (Glass ceiling. Limits in the advancement of women in the workplace). Obnovljeni život, Vol. 65, No. 3, pp. 403-412.

[23] Bogut, Z. (1999). Diskriminacija na tržištu rada (Discrimination in the labor market). Ekonomska misao i praksa, Vol. 8, No. 1, pp. 33-53.

[24] Nestić, D. (2007). Differing characteristics or differing rewards: What is behind the gender wage gap in Croatia?. EIZ.

[25] Leinert Novosel, S. (2003). Politika zapošljavanja žena (Women's employment policy). Politička misao: časopis za politologiju, Vol. 40, No. 3, pp. 103-127.

[26] Daly, M. (2005). Gender mainstreaming in theory and practice. Social Politics: International Studies in Gender, State \& Society, Vol. 12, No. 3, pp. 433-450.

[27] Vasiljević, S., Valković, I. (2007) Vodič za promicanje politike jednakih mogućnosti na radnome mjestu (A guide to promoting equal opportunities policies in the workplace). CESI, Zagreb.

[28] Frgačić, G. (2012). Zašto smo manje plaćene? (Why are we paid less?). Zagreb: v/b/z

[29] Vasiljević, S., Valković, I. (2007) Pravilnik za postizanje jednakih mogućnosti na radnome mjestu (Ordinance for achieving equal opportunities in the workplace). CESI, Zagreb.

[30] Kutnjak, G., Zorić, D., \& Radović, M. (2010). Discrimination of women in contemporary entrepreneurship. Proceedings of the 2nd International Conference "Vallis Aurea" Focus on: Regional Development, 3.9.2010., Požega, Croatia, ISBN: 978-953-7744-06-9, Katalinić, B. (Ed.), pp. 683-691, Vienna: Polytechnic of Požega, Croatia \& DAAAM International Vienna, Austria.

[31] Bilic, A. (2007). Labour Relations in the Republic of Croatia. Zbornik PFZ, No. 57, pp. 1075. 